Article

\title{
Debating the Capabilities of "Chinese Students" for Thinking Critically in Anglophone Universities
}

\author{
Siyi Lu* and Michael Singh
}

Centre for Educational Research, School of Education, Western Sydney University, Penrith, NSW 2751, Australia; m.j.singh@westernsydney.edu.au

* Correspondence: s.lu@westernsydney.edu.au

Academic Editor: James Albright

Received: 26 September 2016; Accepted: 24 January 2017; Published: 4 February 2017

\begin{abstract}
There are media and research reports of international students from the People's Republic of China as being deficient in the capabilities for thinking critically. This paper argues for a shift in the frame for researching their critical thinking, moving the focus from the ethno-national label of "Chinese students" to "multilingual students" and their full linguistic repertoire. This opens up possibilities for exploring definitions of modes of critical thinking in Zhongwen (the official language of China) and English, and the importance of critical thinking in higher education in Australia, China and elsewhere. Attention then turns to constructions of "Chinese students" as uncritical, with explanations for their learning deficit including poor English language proficiency, lack of relevant knowledge, inappropriate assessment and deficiencies in China's educational system. This paper concludes by suggesting research into post-monolingual education may find a theoretic-pedagogical framework that sees multilingual students use their full linguistic repertoire to develop modes of critical thinking while dealing with the tensions posed by English-only monolingual education.
\end{abstract}

Keywords: critical thinking; Chinese international students; uncritical and disengaged; modes of critical thinking in Zhongwen

\section{Introduction}

There are media reports of international students from the People's Republic of China (hereafter referred to as China) as being deficient in the capabilities for thinking critically. A Google search of "Chinese students" and 'critical thinking' brings up newspaper reports with headlines such as:

'Critical thinking, an ability Chinese students [sic] need'; [1]

'Why are Chinese students [sic] lacking capabilities for critical thinking?'; [2]

'International Chinese students [sic] fail courses due to their lack of education in critical thinking'; [3]

'Chinese students [sic] lack of critical thinking due to propaganda'. [4]

These media reports attribute supposed lack of critical thinking capabilities by "Chinese students" to Communist Party propaganda [4], and/or to China's education system and its pedagogical strategies [1,2]. Of course, there are also media posts providing arguments to counter these claims, contending that international students from China do not lack the capabilities for critical thinking. For example, Lee reports that students from China can think critically and are innovative in promoting technology transfer and research from English speaking countries [5]. Likewise, Hernández reports that secondary school students in China outperform their global peers in reading, mathematics and science, which suggests some degree of critical thinking [6]. The long debate about the critical thinking capabilities of "Chinese students" raises educational concerns. Do all university "Chinese students" 
lack these capabilities, or are the capabilities some have for critical thinking not being activated and mobilized in Anglophone universities?

In terms of method, this paper employs an open-minded approach to posing the problem of "Chinese students" and "critical thinking" to open up possibilities for research to produce new evidence with a view of improving education in this field. Here critical thinking is understood as a form of problem-posing which redistributes the prevailing sense and sensibilities that presently construct "Chinese students" as intellectually deficient [7]. Thus, this paper explores the claims made against university students from China through reference to their capabilities for speaking two or more languages. In doing so, this study opens up possibilities for future research into the post-monolingual education for their capabilities for critical thinking [8]. To do so, the students are not labeled "Chinese students" as is the taken for granted practice in both media and scholarly debates.

\section{Multilingual Students: Shifting the Frame for Researching Critical Thinking}

Scholarly debates about the internationalization of higher education in Australia [9-11], China [12-14] and elsewhere $[15,16]$ raise questions about graduates' capabilities for critical thinking. Students can be categorized and labeled in various ways, with different labels having different connotations for how they might be educated. Moreover, as a study by Verkuyten and Thijs shows, the ethnic labeling of groups makes clear the general feelings and sense of difference the majority group members have toward the designated groups [17]. Further, Singh argues that rather than using a single label to categorize out-groups and their differential positioning within a given hierarchy, the use of multiply labels elicits more favorable approaches and more positive evaluations of their capabilities [7]. Building on this research, it is that educators in Anglophone universities may form different impressions of and make inferences about "Chinese students" when they are also described as "multilingual students" studying in English-only universities. This particular proposition could be investigated in future studies. The focus here is on how ethno-linguistically heterogeneous universities might address concerns about the way labels and languages are used.

The multiplication of labels makes possible the recognition that some students from China maybe strong in thinking critically in Zhongwen (the official language of China) and/or English, while others may be weak in one or both languages. There are students from China who can use written Zhongwen to express their critical thinking [18]. There are also some students who can successfully transform their modes of critical thinking in academic Zhongwen into academic English [19]. Then, there are students who cannot demonstrate modes of critical thinking in English [20]. There are also students who lack capabilities, knowledge, dispositions and commitments necessary for critical thinking in any language [21]. It is contended that multiplying the labels and languages used in developing students' capabilities for critical thinking may offer an educationally responsible way forward [7].

Singh's analysis indicates that the label "Chinese students" does two things [7]. First, this label marks these students as belonging to a different social category, namely the category of students from the nation-state of China. Second, this label assigns educational salience to this difference in social category, such as the important factor in these students inability to think critically is that they are from China. Thus, the label "Chinese students" is commonly used in this way to explain these students' alleged inability to think critically. The taken for granted labeling of these students in this way imposes limits on the pedagogies employed to engage them educationally in thinking critically. However, Singh reasons that this is not the only way in which educational engagement with these students and their capabilities for critical thinking might be framed [7]. The label "Chinese students" operates in a particular sociolinguistic context, naming them as students from China rather than students who speak Chinese, English and perhaps other languages or dialects.

This paper argues for a substantial conceptual shift that moves beyond the ethno-national construction of "Chinese students" to focus on their multilingual capabilities. Working with Singh's argument [7], this opens up possibilities for exploring the potential their linguistic repertoire offers for them to access modes of critical thinking in Zhongwen which they might learn to deploy in academic 
English. In terms of both research and education, there may be more to be gained educationally by publically representing these students as speakers of multiple languages, rather than labeling them "Chinese students" to identify them with a particular nation-state.

Recognizing students from China as being speakers of multiple languages means acknowledging that they have linguistic repertoires that could potentially provide them with various modes of critical thinking expressed in Zhongwen [22]. In making this shift from seeing "Chinese students" to seeing "multilingual students" from China, also means moving away from seeing them as "non-English speakers" [23] or "speakers of English as a foreign language" [24]. Instead, as "multilingual students" they speak English, Zhongwen, and one or more dialects or other languages.

Research has shifted the focus to "multilingual students" and their linguistic repertoires, providing a novel framework for reviewing the literature presented in this paper. This opens up a new position for further investigations into this issue. In making this frame shift, this review of relevant scholarly literature relating to "Chinese students" and "critical thinking" avoids the reinvestigation of what is already known [25].

This paper begins by defining the concept of 'critical thinking in Zhongwen' and in English, and then explains the importance of critical thinking in higher education. Evidence of oblique and alternative modes of critical thinking in Zhongwen is then reviewed along with research on students in China engaging in critical thinking. The main section of this paper is devoted to exploring constructions of "Chinese students" as uncritical. To substantiate the claim that "Chinese students" lack the capabilities for critical thinking the literature holds that they lack of relevant knowledge; their English language proficiency is poor; there are problems with the ways critical thinking is assessed in Anglophone universities, and that China's educational system is deficient. The issue at stake here is not the merit of these research findings, but rather what has been consistently omitted from this research, and thus the education of these students. The discussion section raises questions for research that might construct these students as multilingual. Current research in post-monolingual education suggests opportunities for investigating possibilities for these students to develop their capabilities for critical thinking using their full linguistic repertoire.

\section{Defining Critical Thinking and Its Importance}

To bring to the fore questions about the educational uses of multilingual students' linguistic repertoire, this section defines the concepts of "critical thinking in Zhongwen" and "critical thinking in English". It then reviews current literature that highlights the value of critical thinking in higher education, in China and elsewhere.

\subsection{Modes of Critical Thinking in Zhongwen and English}

For Singh the concept of "modes of critical thinking in Zhongwen" designates critical thinking expressed in written Zhongwen (i.e., Hanzi) [7]. This parallels Jullien's use of the terms of "Chinese thought" and "Greek thought" [26]. He uses the concept of "Chinese thought" to designate "the thought which has been expressed in Chinese", just as "Greek thought is that expressed in Greek" [26] (p. 147). Thus, the concept of "modes of critical thinking in Zhongwen" is not to claim that such modes of critical thinking necessarily have a peculiarly Chinese ethno-national essence. In other words, "modes of critical thinking in Zhongwen" can be used by anyone who knows Zhongwen and are in no way restricted to Chinese ethno-nationals. Instead, Singh understands that the modes of critical thinking expressed in Zhongwen are likely to have their equivalent modes of critical thinking in English and other linguistic/cultural contexts [7]. In other words, they are NOT ways of expressing critical thinking that are unique to Chinese people. In contrast, this concept draws attention to the existence of modes of critical thinking in Zhongwen; that at least some of the students who speak this language possibly have knowledge of these modes of critical thinking. Thus, it is their prior knowledge of critical thinking in this language that is potentially available as an educational resource for extending their capabilities in this regard. 
For Chui, modes of critical thinking in Zhongwen involve examining a statement by its "assumptions, the accuracy of supportive evidence and the logical reasoning advanced in reaching conclusions, with sensitivity to situated contexts" [27] (p. 44). Zhong sees modes of critical thinking in Zhongwen as capabilities of identifying the key problem of a given issue or argument, as well as producing reflective thoughts based on logical analysis [28]. Huang considers such modes of critical thinking in Zhongwen to be “智能素质和创造力的重要构成部分 (important components of intellectual quality and creative power)" [29] (p. 69). Further, Dong [30] (p. 64) argues that modes of critical thinking in Zhongwen include:

公正、反思和开放的精神态度与分析、推理、判断、开创等思维技巧的结合, 以理性和 多样性为指导主轴不断寻求知识和合理决策 ... objective, reflective and open-minded disposition, as well as analytic, interpretative, evaluative and innovative thinking skills. [Critical thinking is] driven by rationality and multiple perspectives. [Critical thinking] unceasingly seeks knowledge and reasonable choices.

Ennis defines "modes of critical thinking in English" as the "correct assessing of a statement" and prescribes twelve capabilities for doing so [31]. Then he adds that "modes of critical thinking in English" involve reasonable and reflective thinking which focuses on deciding what to believe or do [32].

Siegel defines modes of critical thinking in English as embodying rationality [33]. Such modes of critical thinking in English build "open-mindedness" [34] (p. 29). In the US, a rational disposition to believe on reasonable and evidential bases is claimed to be a central component of modes of critical thinking in English [35] (p. 87). Further, Siegel adds that modes of critical thinking in English are "not just the competent evaluation of reasons already available, but also the disposition to so evaluate, and to seek and produce further reasons, evidence and arguments relevant to candidate beliefs" [34] (p. 29).

More recently, Paul and Elder see modes of critical thinking in English as the art of "analysing and evaluating a thought with a view of improving it" [36] (p. 4). Moore defines modes of critical thinking in English as comprising components of: judgment; skepticism; a simple originality; sensitive interpretations; rationality; active engagement with knowledge; and self-reflexivity [37]. Willingham defines modes of critical thinking in English as being "open to new evidence that disconfirms your ideas, reasoning dispassionately, demanding that claims be backed by evidence, deducing and inferring conclusions from available facts, solving problems" [38] (p. 8).

Together these definitions indicate the scholarly debate over the concept of critical thinking in both Zhongwen and English. These debates are important because they open spaces for considering innovations for research and education in this field.

\subsection{Critical Thinking in Higher Education}

The rationale for critical thinking in universities in Australia, China and elsewhere has varying grounds for justification. Along with written communication, problem solving and interpersonal understandings, critical thinking is listed as one of four graduate skills supposedly assessed in Australian higher education [9]. In terms of the purpose of Australian education, students demonstrate success as critical thinkers when they are:

(1) able to think deeply and logically, and obtain and evaluate evidence in a disciplined way as the result of studying fundamental disciplines;

(2) creative, innovative and resourceful, and are able to solve problems in ways that draw upon a range of learning areas and disciplines;

(3) able to make sense of their world and think about how things have become the way they are [10] (p. 8).

Lloyd and Nan observe that as critical thinking has gained "heightened attention in higher education", educators have "purposefully integrated critical thinking into student activities, particularly assessment items" [11] (p. 2). 
In China, Wu argues advancing students' critical thinking in university is "an active response to the challenge of the new century" because it helps students to "develop important dispositions" that are required in the changing society [12] (p. 10). Dong argues that “批判性思维是理性和创造性 的核心能力 (critical thinking is a core capability, embodying rationality and creativity)", thus “大学 教育没有批判性思维教育就没有真正的素质教育 (if there is no critical thinking education, there is no real quality-oriented education (素质教育 quality-oriented education is greatly promoted in China in recent years as opposed to 应试教育 examination-oriented education) in higher education)" [30] (p. 64). Students with inadequate capabilities for critical thinking are characterized as “有知识没思想, 有智商 没智慧 (having knowledge yet no thinking; having intelligence yet no wisdom)" [14] (p. 10).

Dwyer, Boswell, and Elliott argue that in Ireland, critical thinking capabilities enable students to understand the complexity of the knowledge they encounter; to use it strategically, and to generate knowledge themselves [15]. Abrami and colleagues in Canada argue that critical thinking is "a fundamental aim and an overriding ideal of education" because it supposedly provides graduates with "a better future as functional and contributing adults" [16] (pp. 2206, 2207).

However, a problem has arisen with the meaning and purpose of "critical thinking" being narrowed, being reduced to a "Western" phenomenon. Egege and Kutieleh argue that teaching critical thinking to Chinese students means "teaching foreign notions to foreign students" [39] (p. 75). The claim is that Western Anglophone students are considered as "experienced students [who] are already enculturated into Western style of [critical thinking]" [40] (p. 18). Rather naively, here critical thinking is constructed as a supposedly unique "Western" mode of expression. Not surprisingly, some monolingual English-speaking academics see themselves as responsible for transferring modes of critical thinking in English to allegedly less-than-critical students of non-English speaking backgrounds [41,42]. No wonder Chui makes the equally questionable claim that critical thinking and associated attributes "are alien to the norms" to students in China [27] (p. 42). The stance adopted in this research means that academics in Australia, China and elsewhere can ignore the modes of critical thinking practiced by multilingual students from diverse intellectual cultures. However, while there is no such a thing as an exclusively "Western" or "Chinese" mode of critical thinking, this research marginalizes the impulse for academics to investigate inter-language innovation and creativity in critical thinking.

However, good education holds that it is important to use the knowledge students already have as intellectual resources in learning new knowledge [43]. For Raineri, privileging modes of critical thinking in English means neglecting modes of critical thinking in other languages, and discourages "consideration of, if not outright ignoring, the...minds and contributions that are at risk of being lost" to study and research [44] (p. 105). In other words, an education that activates multilingual students' modes of critical thinking in their various languages may provide a means of scaffolding the extension of their modes of critical thinking in English [7]. Some multilingual students at least might reshape and recombine their knowledge of modes of critical thinking from their linguistic repertoire in order to deepen their capabilities in this regard.

\section{Oblique and Alternative Modes of Critical Thinking in Zhongwen}

This section reviews research reporting selected modes of critical thinking in Zhongwen. Here the focus is on the significance of oblique and alternative modes of critical thinking in Zhongwen. Research into students' engagement with such modes of critical thinking is also reviewed.

There are modes of critical thinking in Zhongwen related to China's social history. Intellectuals in China are familiar with the consequences of exercising critical thinking, because history has taught them lessons about violent censorship [45]. Davies argues that "systematic political pressure" has produced the "pervasive practice of self-censorship among Chinese intellectuals" [46] (p. 4). Accordingly, Davies notes that Chinese scholars have to "detect where the border between safety and punishment is at any given moment" when thinking critically [46] (p. 4). They invest time in finding a balance between what 
they need to say and what they can say: "state censorship and an abiding sense of cultural subjugation impose powerful limitations on mainland Sinophone scholarship" [46] (p. 35).

Further, the demands of Confucian intellectual culture are another constraint on critical thinking in China. Confucianism is used to censor or suppress critical thinking by giving power to the values of balance, stability and harmony. These value/power mechanisms are used in China to justify "respect in speech", which in Hostettler's view means that an individual's academic freedom to express critical thinking "is secondary to the shared rights of society" [47] (p. 72) Allowing individuals to air their critical thinking freely to confront the injustices of society can do serious harm to the harmony and productivity of the society, especially when such critical thinking causes problems for elites. Therefore, critical thinking is framed by the expectation "the rights of the speaker must be taken into consideration in conjunction with the rights of the listeners" [47] (p. 73).

Critical thinking is restrained by moral responsibility and concerns about its uncertain consequence. The question that has to be asked here is, how do these socio-historical drivers influence the modes of critical thinking employed by students in China? Under the circumstances, Wang argues that China's educational culture encourages unquestioning respect for authority and advocates conformity in thinking, so students are required to listen quietly and carefully to academics and not to cause trouble in university [48]. This educational culture suppresses students' critical potential, and produces 'well-behaved' students and a teacher-centered pedagogy.

The advocacy of harmony and its reinforcement through censorship has resulted in the cautious exercise of intellectual autonomy by China's critical thinkers [45-47]. Not surprisingly, there are various ways that people in China may strive to give expressions to their critical thinking. In particular, they may not express their critical thinking directly. Instead, they write in ways which assume that informed audiences/readers can nonetheless interpret their tacit critical thinking expressed in Zhongwen. An important mode of critical thinking in Zhongwen is the ability to express and convey one's critical thinking obliquely from the writer to the readers $[45,46,49]$. They use oblique modes of critical thinking to maintain their livelihood through modes of expression that avoid unwarranted confrontations. Research has been done on the creative ways used to express oblique modes of critical thinking in Zhongwen. Bridges speaks of an innovative public "community of arguers, enquirers and critics" in China who use its intellectual heritage to express their critical thinking [50] (p. 66). The abundance of homophones in Zhongwen provides many opportunities for oblique modes of critical thinking. For instance, Wang records how an intellectual cryptically used a couplet to express critical thinking: 生如夏花, 却被折下 “Sheng ru xiahua, que bei zhexia, life is as summer flowers, but it is snapped off". Here 生 sheng can also mean "student(s)". Knowing readers understand this intellectual is referring to the experiences of students during the chaos of the Cultural Revolution, means that this couplet can be read as an oblique mode of critical thinking, as 'the students were as summer flowers, but they suffered from the disaster of the time' [51].

Evidence of modes of critical thinking in Zhongwen can also be found in the everyday sociolinguistic practices of students in China. Wang reports that university students playfully rewrite the educational concept “因材施教 (yin cai shi jiao, teaching according to aptitude)" as “因财施教 (yin cai shi jiao, teaching according to money)" [18]. Here students replace “材 (cai aptitude)" with its homophone of “财 (cai money)" to change the meaning of the concept while remaining the same pronunciation. When students speak of this concept, it would still be perceived as “因材施教 (yin cai shi jiao, teaching according to aptitude)". While in writing, the reinvented concept of “因财施教 (yin cai shi jiao, teaching according to money)" subtly illustrates their critical thinking regarding the injustices they observed in their educational environment. This instance of critical thinking alludes to the problem whereby some university academics in China show no passion in teaching. They only take their teaching responsibilities as a matter of delivering textbook content to students so they can get paid [52]. Here then students' critical thinking questions the money-related relationship between teachers and students, and points to the commercialization of education. 
Modes of critical thinking in Zhongwen entail the deliberate use of the same Hanzi (character) to produce sentences suggesting two distinct meanings. A familiar online message states, first year university students say, 喜欢一个人, while in their last year they say, 喜欢一个人. The sentences are exactly the same, but their meanings regarding students' personal development are markedly different. This is made possible by laying the stress on different words. The word “一个人" can be interpreted as “一个, 人 (yi ge, ren, a person)" and “一个人 (yi ge ren, one person alone)". If the stress is laid on "喜欢xi huan", as in “喜欢一个人 (xi huan yi ge ren)", the sentence would be perceived as "love another person". In contrast, when the stress is laid on “一个人 (yi ge ren)", as in “喜欢一个人 (xi huan yi ge ren)", the sentence can mean "love to be alone". The first sentence refers to students' need to establish their sense of belonging based upon the approval of others. The second statement speaks to their growing appreciation of independence [53]. Knowing these two possible interpretations, the written text of this sentence can be understood differently according to context.

These students' modes of critical thinking in Zhongwen are playful and meaningful. Their critical thinking may be characterized as "creative, innovative" in making sense of "their world and think about how things have become the way they are" [10] (p. 8). Conscious of operating in China's social, cultural and educational environments, these students take care with their modes of critical thinking. They take an indirect approach to expressing their critical thinking about the targeted issues [46,54]. In an English-only educational environment, such modes of critical thinking in Zhongwen are not evident. Singh contends that the issue here is to develop pedagogies for effectively translating these into English so that such multilingual students can deepen and extend their critical thinking [7].

The following section examines how researchers construct and debate the critical thinking capabilities of international students from China studying in Anglophone universities. As will be seen, these multilingual students are often criticized for their inability to think critically in English [20,55]. Working within an English-only monolingual framework, the failure of these students to think critically is attributed to deficiencies in China's education system which is said to value the production of uncritical learners [56-58].

\section{Construction of "Chinese Students" as Uncritical}

There is literature that characterizes international students from China as uncritical. For instance, Asmar argues that Anglophone universities see many of these international students needing remedial education to compensate for deficits due to their lack of critical thinking capabilities [59]. China's People's Daily (Overseas Edition, 2010) reports President Levin of Yale University as stating at the Fourth Chinese-Foreign University Presidents Forum: “批判性思维是中国留学生缺乏的 (Chinese international students are lacking the capabilities for critical thinking)" [60]. Similarly, Clark and Gieve argue that international students from China are regarded by their monolingual English-speaking educators as "lacking the capacity for critical thinking"; their "failure" in this regard is attributed to China's educational culture, and as a consequence Anglophone education has the burden of remedying their "deficiencies" in critical thinking [20] (p. 56). Supervisors from an Anglophone university have indicated that "developing criticality is a very slow process" for some Chinese students [21] (p. 595). Tian and Low note the paradox where university teachers in China avoid teaching critical thinking because it is not required in examinations, even though they place "a high value on it and saw it as something they recognized that they ought to be teaching" [61] (p. 69).

This research points to "Chinese students" studying in Anglophone universities as lacking the capabilities for critical thinking. According to Singh's analysis this construction of "Chinese students" as uncritical frames them in terms of ethnicity or nation-state identity [7]. He argues that possibilities for innovative pedagogies that take into account multilingual students' full repertoire of linguistic when teaching critical thinking are denied by this construction [7]. However, each of the following sections which provide possible explanations to why "Chinese students" are uncritical compounds this prevailing construction. This construction of 'Chinese students" is opened up to scholarly debate by a proposal in each case to explore a different angle through which to these students might be positioned 
and through which they might better position themselves. This then presents new possibilities for researching pedagogical innovation and improvements in the education of multilingual students.

\subsection{Lack of Relevant Knowledge}

Research also raises the question about whether students from China lack adequate understanding of what meant by 'critical thinking'. Tian and Low found that some monolingual English-speaking academics see international students from China, as being "unclear about how to 'be critical' in an appropriate way, and thus become actively worried about their own critical thinking performance" [61] (p. 64).

Zhao and MacDougall explain students from China lack of critical thinking because they "may not know the theories, concepts, norms, terms, and so on of a particular academic discipline" [62] (p. 65). O'Sullivan and Guo trace the problem these students have with critical thinking as being due to its absence from "Chinese education discourse at both secondary and postsecondary level" [63] (p. 54). In the words of one student interviewee, "critical thinking was never formally introduced during Chinese classes" [63] (p. 54). Her monolingual English-speaking professor's comments on her assignments "frequently made reference to lack of criticality" [63] (p. 54). Chan, Ho and Ku argue that there is "clear evidence" that students from China tend to "devaluate or ignore counterarguments" [64] (p. 67), due to their lack of exposure to open-minded education which values critical thinking.

A lack of relevant knowledge is said to explain the prevailing constructions of "Chinese students" as uncritical. Singh notes that this claim is made despite the educational idea of using what students already know to scaffold their learning of new material [7]. The double barrel deficit in terms of a lack of knowledge and a lack of ability to think critically squeezes any consideration of using students' prior learning as part of pedagogies which possibly use multilingual students' full linguistic repertoire.

\subsection{Poor English Language Proficiency}

Research states that the silence of students from China in class is a sign of their passivity and an unwillingness to participate in critical thinking $[56,65,66]$. However, this silence can be attributed to their inadequate capabilities for speaking English. Ping contends that these students" "silent in-class behaviour" is due to their limited English, and this is a barrier to them learning to think critically [67] (p. 208). Their quietness during discussions is construed as "reluctance to participate" critically in class, while in reality they may just feel nervous about their level of English [67] (p. 208). Mak points out that these students feel uncomfortable about exchanging critical thoughts with native speakers of English because of their own poor English language proficiency [68] (p. 210). Liu and Jackson trace these students' seemingly uncritical behavior to their fear of being negatively evaluated by their peers and educators because they cannot communicate in English fluently [69]. In this sense, these students' poor English proficiency is seen as a reason for their unwillingness to engage in critical and meaningful interactions.

Yet at the same time Zhang and Mi observe that not all Chinese students are so vulnerable in their English ability [70]. Difficulties with listening to and speaking English are largely confined to the first two years of studies in Anglophone universities. Moreover, this does "not seem to affect the academic study of those informants in linguistically less demanding courses" [70] (p. 371). Overall, this literature, which focuses on deficit constructions of students from China holds that their poor English language proficiency condemns them to failure in critical thinking $[20,21,39,59]$.

Poor English language proficiency is added to the students' alleged lack of knowledge and lack of ability to think critically to explain the prevailing constructions of "Chinese students" as uncritical. Here it must be asked, rhetorically, why do Anglophone universities recruit so many international students in those from China? Given the financial stake these universities having in recruiting students' from China, alternative pedagogies which use multilingual students' full linguistic repertoire might be beneficial to all interests at stake here. 


\subsection{Problematizing Assessment of Critical Thinking}

So far, this paper has reviewed research constructing "Chinese students" as uncritical, and explaining this in terms of their lack of contextually relevant knowledge and Poor English language proficiency. Research reports that another factor obstructing the demonstration of their capabilities for critical thinking is the limitations of assessment instruments.

O'Loughlin points to problems with standardized English-only tests to gauge the critical thinking ability of students from China [71]. Such tests make invalid assumptions of second-language English competence. Alison and Lee note the "countless submissions for assessment by international students [from China] currently studying at Australian universities [who know they] attract criticism for their efforts to communicate in English" [72] (p. 21). This is compounded by a stereotyped construction of these students as "uncritical, rote and passive-learners who are linguistically unprepared for their study" [72] (p. 21).

O'Sullivan and Guo argue there is an assumption by Anglophone academics that "the concept and practice of critical thinking has been mastered by their students, including international students" [63] (p. 54). Therefore, students from China should develop "good critical thinking skills" assessable in terms of their expected professional demands [63] (p. 54). However, Shohamy claims that although international students from China acquire vast amounts of academic knowledge, it is not always possible to adequately assess that knowledge through tests conducted in a different socio-cultural context through a different language [73] (p. 419). Further, Shohamy argues that tests used in Anglophone universities evaluate critical thinking from an English-only monolingual perspective mask the actual level of students' critical thinking so that valid assessment is compromised [73].

$\mathrm{Ku}$ is concerned that critical thinking tests which use "a single multiple-choice response format [only measures] responses to certain types of knowledge" [74] (p. 70). Lack of familiarity with a topic also adversely affects students' level of critical thinking, including monolingual English-speaking students [61]. Ryan and Viete argue that university requirements for students from China to use only academic English at an advanced level in their university studies may disadvantage their assessment outcomes [75].

English-only assessment is pervasive in Anglophone universities. From a monolingual perspective this is to be expected and seems necessary. For instance, Swain et al. detect a sense of guilt by teachers of English classes in Hong Kong "every time they use Cantonese in their classes", because they are urged to use English "in all English lessons and beyond" [76] (p. 2). Moreover, universities in Hong Kong have warned teachers-in-training, that "Cantonese must not be used in English classes" [76] (p. 2). Monolingualism is the reigning pedagogical framework in education. Singh and Shrestha report that as they confront assessment criteria privileging modes of critical thinking in English, students from China "have to admit to the inappropriateness of the culturally ingrained strategies they have learned for composing essays" [77] (p. 67). They argue that the dominance of English-only modes of assessment neglect these students' prior knowledge of modes of critical thinking in Zhongwen. A student made the effects of such linguistic dominance evident in an interview:

All the [Australian] teachers would try to help me to "adapt". I was told by one of my lecturers, and one of the academic advisers, that we are not testing for what I already know; we are testing you for what you learnt in this class. [78]

Problematizing the assessment of critical thinking by Anglophone universities presents one way of tackling the prevailing constructions of "Chinese students" as uncritical. There may be credible grounds to argue that assessments of Chinese international students' critical thinking in monolingual Anglophone universities may be inadequate and/or invalid. However, this does not address their alleged deficits in terms of poor English language proficiency or lack of contextually, relevant knowledge. Singh holds that a singular focus on testing does not address the issue of whether more innovative pedagogies that activate multilingual students' full linguistic repertoire might provide them access to educational resources for deepening their critical thinking [7]. This would then provide 
a basis for arguing that the means used to assess these students' critical thinking do not provide for the translanguaging practices that might enable them to better demonstrate these capabilities.

\subsection{A Deficient Educational System}

China's supposedly rote learning system is held to be antithetical to the critical thinking that is purportedly valued by Anglophone universities. Durkin says that China's education system takes knowledge as "absolute, defined by an authority as right or wrong [and] expects expository teaching with the focus on content and reproduction of material in their assignments" [40] (p. 18). Likewise, Liu and $\mathrm{Hu}$ (2005) report that academics in China use textbooks and examinations to "measure the mere apparent achievements of students . . . for the sake of standardization" [58] (p. 10). They argue that there is supposedly always one correct answer to the questions on examination papers, so teachers avoid the "diversity of critical thinking [in order to] systematise the correct answer" to those questions [58] (p. 10). Huang argues that "a test-driven approach is still a strong existent in the Chinese classroom [where] parents and teachers often gravitate toward spoon-fed styles of teaching that promote the pattern of rote memorisation" [57] (p. 252).

A study by Fairbrother found that Chinese students agreed that "indoctrination" was part of their secondary schooling [56] (p. 613). Some students claimed that textbooks implanted information in their minds, so that when a topic was mentioned on an examination paper the answer was instantly triggered apparently without thinking. Kirkpatrick and Zang argue that this particular pedagogical approach "can stifle a student's imagination, creativity, and sense of self," all of which are significant qualities for a student to achieve success in critical thinking [79] (p. 43). Tran reports that students in China are viewed as "perplexed, deficient and handicapped by some Anglophone scholars" because the China's education system demotivates them from "thinking critically" [55] (p. 59). Research by Turner found that high-achieving Chinese students may even show a "decline in critical commitment-engagement over the course of an undergraduate degree" rather than the opposite [80] (p. 4).

Researchers studying Chinese students' critical thinking capabilities frequently question China's teacher-centered pedagogy. Deng and Pei note that under the "whole classroom teaching mode" students are expected to "hide their curiosity and self-identity and try to be as same as others" [66] (p. 319). Xie (cited in [61]) argues that the educational participation structure socialises "students into being a particular type of learner [where] the teachers has absolute authority over them; [the students say] things only when being asked to and to say things that the teachers wants to hear" (p. 69). Zhao and McDougall note that students in China prefer to "respond closely to the instructor's questions" [62] (p. 64). As a result, even if they think critically in respond to the textbook, they may still "not go beyond the instructors' expectation and thus sound uncritical" [62] (p. 64). Moreover, by doing so, students are considered well-behaved.

Research has revealed that the capabilities students in China have for critical thinking are restrained by them being trained to value themselves according to the grades they are given. Liu and Hu note that in China a student's standing is established according to his or her grades [58]. Marsh and Rowlinson found students in China lack confidence in their ability to think critically [81] (p. 397) about problems, unable to access, interpret and apply "information learned primarily through a self-directed investigation of the resources currently available" [58] (p. 11). Yan and Berliner report that international students from China believe that "good grades bring a feeling of self-esteem and self-worth" [82] (p. 179), and attach little value to good critical thinking capabilities. Bodycott observes that for these students critical thinking does not guarantee a good grade and as such is considered a "distraction" [83] (p. 358).

Such accounts of the Chinese education system, and the roles of students and academics in this system, have gained the status of conventional wisdom for explaining the difficulties faced in thinking critically. However, the literature presents evidence that offers other views and interpretations.

Research has established that the learning strategies of students from China are more complicated than it looks on the surface. Watkins and Biggs report on the paradox of these students being 
stereotyped in Anglophone universities for passively memorizing what they are taught on the one hand, and on the other hand, supposedly outshining their Anglophone peers in international comparisons of academic achievement, especially in science and mathematics [84,85]. Biggs explains that a strategy used widely in education throughout China is 书读百遍其义自见 ( $s h u$ du bai bian qi yi zi xian), which means repetition is the route to understanding. That is to say, certain students' approach to learning complex content is, purportedly to build meaningful understanding through deep memorization based on reflective repetition [85]. Watkins reports that some students in China apparently believe understanding to be a long process which requires extensive personal effort of them, with such effort being demonstrated through exploring ideas via repetition and memorization [84].

In their study, Li and Wegerif see the image of China's education alleged system of rote learning deriving from students' quiet behavior in class [86]. Yet this quiet learning strategy may lead to in-depth understanding of "the forms of inner dialogue between multiple voices in the context of relationships and responsibilities" [86] (p. 22). Here it is worth noting Sit's point that in China's educational system, some students at least do "value thoughtful questions which they ask after sound reflection" [87] (p. 38). However, the significance of the complexities and contradictions in China's education system tend to be overlooked, perhaps "because it does not fit easily with more demonstrative and individualistic traditions of teaching thinking familiar in the West" [87] (p. 22). Nevertheless, characterizing China's education system as driven exclusively by non-participative rote learning may be overly simplistic.

The claim here is that the prevailing construction of "Chinese students" as uncritical is to be explained a deficient education system. For Singh this means that innovative pedagogical possibilities for the teaching critical thinking that accounts for students' multilingual capabilities are denied [7]. In particular, within this deficit framework there is no scope for considering the educational uses of their repertoire of linguistic, despite the claims liberal education makes for using students' prior learning.

In sum, much of the literature reviewed here focuses on "Chinese students" as lacking the capabilities for critical thinking. The reasons for this are said to be that "Chinese students" lack of relevant knowledge, have poor English language proficiency, and Anglophone universities have problems with assessing their critical thinking. Moreover, educational system of one of the world's leading economies is said to be deficient, at least in terms of preparing "Chinese students" to study in Anglophone universities. Apart from the immense amount of money these universities make from full-fee-paying students from China, it seems they fail to meet the entry requirements of these universities which seem to have few educational reasons for recruiting so many of them. However, if Anglophone universities do continue to recruit students from China, then as Singh argues there is warrant for shifting the frame for researching (and teaching) critical thinking [7]. One particular shift might be to move from the label "Chinese students" with its two dimensional focus on their ethno-national and non-English speaking backgrounds to a focus on them as "multilingual students" [7]. To open up this issue to further research the next section explore the prospects a post-monolingual orientation might offer for the education of multilingual students' capabilities for thinking critically. Current research suggests post-monolingual education could provide a framework for investigating the possibilities for these students to use their full linguistic repertoire to develop their capabilities for critical thinking.

\section{A Post-Monolingual Orientation to Education for Critical Thinking}

There is research which constructs 'deficit views' of what are labeled as "Chinese students" who are said to lack the capability for successfully employing modes of critical thinking in English. This research attributes this deficiency among "Chinese students" to poor English language proficiency, lack of relevant knowledge, inappropriate assessment and China's education system [20,39,59,73,75]. However, this research has resulted in little improvements in Anglophone universities efforts to remediate this apparent deficit in their education, let alone China's intellectual culture. 
The particular sociolinguistic context in which the label "Chinese students" and their categorization as deficient in critical thinking skills operates as one of English-only monolingual theory, pedagogies and policies [7]. The power that privileges English-only monolingualism impacts on students from China by marginalizing their speaking of Chinese, along with other languages or dialects. Despite, or because of the drive to internationalize education by Anglophone universities the expectation is that students from China will learn modes of critical thinking in English. Thus, any theoretic-pedagogical framework that seeks to activate and mobilize multilingual students' modes of critical thinking across their full linguistic repertoire has to explicitly incorporate engagement with the tensions posed by English-only monolingualism. Moreover, given the massive financial dependency these universities have on full-fee paying students from China [71,78], a shift in the framework employing for researching their education in critical thinking seems warranted.

Post-monolingual education has the potential for providing such a theoretic-pedagogical framework [88]. This entails multilingual students using modes of critical thinking from their full linguistic repertoire, and rather than just using modes of critical thinking in English [7]. Moreover, multilingual students are asked to explore the tensions their investment in English language education creates along with the challenges posed English-only monolingual education. For instance, they might direct their critical thinking to labels such as 'people from non-English speaking backgrounds'. In developing their post-monolingual capabilities for theorizing, multilingual students could produce evidence of their knowledge of these practices, how their capabilities are being extended, and critically reflect on the value and valuing of these capabilities.

Singh's research supplements existing studies which use the single label of "Chinese students", categorizes them as an out-group of deficit learners and positions their ability for critical thinking within a differential hierarchy that privileges English-only monolingualism [7]. This research has given rise to a pedagogical model for negotiating modes of critical thinking through multilingual resources rather than forcing students to choose monolingual rhetorical strategies [7], irrespective of whether it is Zhongwen-only or English-only [89]. Singh's research, which uses a multi-dimensional framework, is eliciting more productive pedagogies and more positive evaluations of multilingual students' capabilities [7]. Through such research, Anglophone universities and their academics may formulate new methods for working with multilingual students and the modes of critical thinking available across their linguistic repertoire. This particular proposition which calls for the multiplying of the labels, categories and hierarchies employed in researching the education of multilingual students in modes of critical thinking warrants investigation in future studies.

To reiterate, the term 'modes of critical thinking in Zhongwen' does not mean that people of China have some exceptional or unique methods for thinking critically. Rather, this term focuses attention on modes of critical thinking in languages other than English, and brings into focus the linguistic repertoire that multilingual students have available for expressing their critical thinking. The term 'modes of critical thinking in Zhongwen' draws attention to international students from China being multilingual, and that their Zhongwen language is used for express various modes of critical thinking [7]. Thus, these students might be pressed to draw upon their existing knowledge of 'modes of critical thinking in Zhongwen' to scaffold their learning of modes of critical thinking in English. Research is needed to ascertain the benefits or otherwise of having multilingual students use the modes of critical thinking available in their linguistic repertoire to extend and deepen their capability for thinking critically across their complete repertoire and contribute to their academic success in Anglophone universities.

Post-monolingual education creates multi-modal translanguaging contact zones for critical thinking that draw upon multiple and ever contested linguistic repertoire of students from China [88] (p. 160). Importantly, through its collaborative, reciprocal intellectual interactions this pedagogical intervention mobilizes multiple linguistic resources that may facilitate the co-production of Anglo-Chinese modes of critical thinking [88] (p. 158). Research into post-monolingual pedagogies is necessary to establish how such multilingual students might develop their capabilities for translating, 
re-conceptualizing and contextualizing modes of critical thinking in Zhongwen through writing in academic English.

\section{Conclusions}

The significance of this paper to the scholarly debates over the "Chinese students" and their capabilities for 'thinking critically' is in opening up possibilities for a shift in research away from English-only monolingual theory, pedagogies and policies. The evidence, concepts, and arguments considered in this paper give warrant for researching pedagogies that are informed by post-monolingual education $[8,77,88]$. Recognizing that students' multilingual capabilities exist in tension with English-only monolingualism, including its labels, categories and hierarchies, opens up possibilities for researching modes of critical thinking in Zhongwen and ways of using trasnlanguaging practices to extend students' capabilities for using modes of critical thinking in English [7]. Moreover, further research is necessary to examine the processes whereby universities which operate within an English-only monolingual framework might make moves to recognize and accredit multilingual students' academic uses of complete linguistic repertoire.

Conflicts of Interest: The author declares no conflict of interest.

\section{References}

1. Zhu, J. Critical thinking, an ability Chinese students need. China Daily, 9 June 2015. Available online: http://www.chinadaily.com.cn/opinion/2015-06/09/content_20945294 (accessed on 9 June 2015).

2. $\mathrm{Hu}, \mathrm{L}$. Why Chinese students are lack of capabilities for critical thinking. Nanfang Media (南方都市报), 29 October 2012. Available online: http://www.takungpao.com/opinion/content/2012-10/29/content_ 1309095.htm (accessed on 29 October 2012).

3. Chen, B. International Chinese students fail courses due to their lack of education in critical thinking. Gmwcn (光明教育), 17 August 2015. Available online: http://edu.gmw.cn/2015-08/17/content_16699964.htm (accessed on 17 August 2015).

4. Matthews, D. Chinese students lack critical thinking 'due to propaganda'. Times Higher Education, 19 March 2007. Available online: https://www.timeshighereducation.com/news/chinese-students-lackcritical-thinking-due-propaganda (accessed on 19 March 2007).

5. Lee, J. Chinese innovation: More than a fast follower? (Part 2). Interpreter, 9 June 2016. Available online: http:/ /www.lowyinterpreter.org/post/2016/06/09/Chinese-innovation-More-than-afast-follower-Part-2.aspx (accessed on 9 June 2016).

6. Hernández, J. Study finds Chinese students excel in critical thinking. The New York Times, 30 July 2016. Available online: http://www.nytimes.com/2016/07/31/world/asia/china-college-education-quality. html?_r=0 (accessed on 30 July 2016).

7. Singh, M. Multilingualism, problem-posing and critical writing: Chinese students' innovative challenges to constructions of themselves as 'uncritical'. In Rethinking Languages Education: Directions, Challenges and Innovations; Arber, R., Weinmann, M., Blackmore, J., Eds.; Routledge: London, UK, 2017; in press.

8. Singh, M. Urban education across the post-colonial, post-Cold War South Pacific: Changes in the trans-national order of theorizing. In Second International Handbook of Urban Education; Pink, W., Noblit, G., Eds.; Springer: Geneva, Switzerland, 2016; pp. 913-932.

9. Nelson, G. Our Universities: Backing Australia's Future; Commonwealth of Australia: Canberra, Australia, 2003.

10. Ministerial Council on Education, Employment, Training and Youth Affairs (MCEETYA). Educational Goals for Young Australians. 2008.

11. Lloyd, M.; Nan, B. Thinking Critically about Critical Thinking in Higher Education. Int. J. Scholarsh. Teach. Learn. 2010, 4, 2-16.

12. Wu, H. Critical thinking. J. Guangzhou Univ. Soc. Sci. Ed. 2004, 3, 10-16.

13. Zhu, X. Developing university students' capabilities for critical thinking: Meaning and strategy (大学生批判 性思维培养: 意义与策略). J. South China Normal University (华南师范大学学报) 2006, 3, 123-126.

14. Liu, R. The significance and connotation of critical thinking (论批判性思维的意义和内涵). Teach. Educ. Res. (高等师范教育研究) 2000, 1, 9-11. 
15. Dwyer, C.; Boswell, A.; Elliott, M. An evaluation of critical thinking competencies in business settings. J. Educ. Bus. 2015, 90, 260-269. [CrossRef]

16. Abrami, P.; Bernard, R.; Borokhovski, E.; Wade, A.; Surkes, M.; Tamim, R.; Zhang, D. Instructional interventions affecting critical thinking skills and dispositions: A stage 1 meta-analysis. Rev. Educ. Res. 2008, 78, 1102-1134. [CrossRef]

17. Verkuyten, M.; Thijs, J. Ethnic minority labeling, multiculturalism, and the attitude of majority group members. J. Lang. Soc. Psychol. 2010, 29, 467-477. [CrossRef]

18. Wang, P. To see college cultural spirit from campus popular words. J. Zhejiang Text. Fash. Vocat. Coll. 2011, 2, 79-84.

19. Singh, M.; Meng, H. Democratising western research using non-western theories. Stud. High. Educ. 2011, 38, 907-920. [CrossRef]

20. Clark, R.; Gieve, S. On the discursive construction of 'the Chinese learner'. Lang. Cult. Curric. 2006, 19, 54-73. [CrossRef]

21. Goode, J. Empowering or disempowering the international Ph.D. student? Constructions of the dependent and independent learner. Br. J. Sociol. Educ. 2007, 28, 589-603. [CrossRef]

22. Singh, M.; Harreveld, B.; Gao, T.; Danaher, P. Mobility and local/international knowledge co-production: Innovation in the post-monolingual learning of Chinese. In Mobile Teachers, Teacher Identity and International Schooling; Arber, R., Blackmore, J., Vongalis-Macrow, A., Eds.; Sense: Dordrecht, The Netherlands, 2015; pp. 121-139.

23. Aiguo, W. Teaching aviation English in the Chinese context: Developing ESP theory in a non-English speaking country. Engl. Specif. Purp. 2007, 26, 121-128. [CrossRef]

24. González, V.; Chen, C.; Sanchez, C. Cultural thinking and discourse organizational patterns influencing writing skills in a Chinese English-as-a-foreign-language (EFL) learner. Biling. Res. J. 2001, 25, 627-652. [CrossRef]

25. Vom Brocke, J.; Simons, A.; Niehaves, B.; Reimer, K.; Plattfaut, R.; Cleven, A. Reconstructing the giant: On the importance of rigour in documenting the literature search process. ECIS Proc. 2009, 9, 2206-2217.

26. Jullien, F. On the Universal, the Uniform, the Common and Dialogue between Culture; Richardson, M., Fijakowski, K., Translators; Polity Press: Cambridge, UK, 2014.

27. Chui, Y. Facilitating Asian students' critical thinking in online discussions. Br. J. Educ. Technol. 2009, 40, 42-51. [CrossRef]

28. Zhong, Q. “Critical thinking” and its teaching pedagogy (“批判性思维”及其教学). Global Educ. (全球教育展望) 2002, 3, 4. Available online: http:/ /www.cnki.com.cn/Article/CJFDTotal-WGJN200201007.htm (accessed on 16 December 2016).

29. Huang, C. Extending critical thinking education and cultivating innovative individuals (加强批判性思维教 育培养创新型人才). Educ. Res. (教育研究) 2010, 5, 69-74.

30. Dong, Y. Debating the three misunderstandings of critical thinking (批判性思维三大误解辨析). J. High. Educ. (高等教育研究) 2012, 11, 64-70.

31. Ennis, R.H. A concept of critical thinking. Harv. Educ. Rev. 1962, 32, 81-111.

32. Ennis, R.H. Critical thinking assessment. Theory Pract. 1993, 32, 179-186. [CrossRef]

33. Siegel, H. Critical thinking as an educational ideal. Educ. Forum 1980, 45, 7-23. [CrossRef]

34. Siegel, H. Open-mindedness, Critical Thinking, and Indoctrination: Homage to William Hare. Paideusis 2009, 18, 26-34.

35. Siegel, H. Educating Reason: Rationality, Critical Thinking, and Education; Routledge: London, UK, 1988.

36. Paul, R.; Elder, L. Critical Thinking: Concepts and Tools; Foundation for Critical Thinking Press: Dillon Beach, CA, USA, 2008.

37. Moore, T. Critical thinking: Seven definitions in search of a concept. Stud. High. Educ. 2013, 38, 506-522. [CrossRef]

38. Willingham, D.T. Critical thinking: Why is it so hard to teach? Am. Educ. 2007, 109, 8-19. [CrossRef]

39. Egege, S.; Kutieleh, S. Critical thinking: Teaching foreign notions to foreign students. Int. Educ. J. 2004, 4, 75-85.

40. Durkin, K. The adaptation of East Asian masters students to Western norms of critical thinking and argumentation in the UK. Int. Educ. 2008, 19, 15-27. [CrossRef]

41. Singh, M. Using Chinese knowledge in internationalising research education. Glob. Soc. Educ. 2009, 7, $185-201$. 
42. Singh, M. Learning from China to internationalise Australian research education. Innov. Educ. Teach. Int. 2011, 48, 395-405. [CrossRef]

43. Alguezaui, S.; Filieri, R. A knowledge-based view of the extending enterprise for enhancing a collaborative innovation advantage. Int. J. Agil. Syst. Manag. 2014, 7, 116-132. [CrossRef]

44. Raineri, N. Business doctoral education as a liminal period of transition: Comparing theory and practice. Crit. Perspect. Account. 2015, 26, 99-107. [CrossRef]

45. Berry, M. A History of Pain: Trauma in Modern Chinese Literature and Film; Columbia University Press: New York, NY, USA, 2011.

46. Davies, G. Worrying about China: The Language of Chinese Critical Inquiry; Harvard University Press: New York, NY, USA, 2007.

47. Hostettler, N. Tongue in cheek: How internet defamation laws of the United States \& China are shaping global internet speech. J. High Technol. Law 2009, 9, 66-88.

48. Wang, L. The differences between the Chinese and English Modes of thinking and paragraph structure in English argumentative writing. J. Shang Luo Teach. Coll. 2006, 20, 25-30.

49. Xu, M. Debating the Image of Zhao Xinmei in WeiCheng (试论《围城》中赵辛椐的形象塑造). Chinese Literature Website (中国文学网), 2006. Available online: http:/ /www.literature.org.cn/Article.aspx?id=62768 (accessed on 11 November 2016).

50. Bridges, D. The disciplines and discipline of educational research. Philos. Methodol. Educ. Res. 2006, 40, 259-272. [CrossRef]

51. Wang, S. There is Peace in me like a River (我有平安如江河); Jiangxi People Publishier (江西人民出版社): Nanchang, China, 2009.

52. Jin, Y. Reexamining and reconstructing faculty-student relationship in the university from a cultural perspective. Mod. Univ. Educ. 2013, 1, 28-34.

53. Huaihua College blog (怀化学院吧). Available online: http://tieba.baidu.com/p/2472971084 (accessed on 10 November 2014).

54. Liu, J. Placement of the thesis statement in English and Chinese argumentative essays. Electron. J. Foreign Lang. Teach. 2007, 4, 122-139.

55. Tran, T. Is the learning approach of students from the Confucian heritage culture problematic? Educ. Res. Policy Pract. 2013, 12, 57-65. [CrossRef]

56. Fairbrother, G. The effects of political education and critical thinking on Hong Kong and mainland Chinese university students' national attitudes. Br. J. Soc. Educ. 2003, 24, 605-620. [CrossRef]

57. Huang, S. The use of literacy bags promotes parental involvement in Chinese children's literacy learning in the English language. Lang. Teach. Res. 2013, 17, 251-268. [CrossRef]

58. Liu, Z.; Hu, Z. On the opposite of quality-oriented education to exam-oriented education. Curric. Teach. Mater. Method 2005, 3, 10-14.

59. Asmar, C. Internationalising students. Stud. High. Educ. 2005, 30, 291-309. [CrossRef]

60. People's Daily Overseas Edition. President of Yale University Pointed out Chinese International Students Are Lack of Critical Thinking. Available online: http://edu.people.com.cn/GB/14803191.html (accessed on 3 April 2016).

61. Tian, J.; Low, G. Critical thinking and Chinese university students: A review of the evidence. Lang. Cult. Curric. 2011, 24, 61-76. [CrossRef]

62. Zhao, N.; McDougall, D. Cultural influences on Chinese students' asynchronous online learning in a Canadian university. Int. J. E-Learn. Distance Educ. 2008, 22, 59-80.

63. O'Sullivan, M.; Guo, L. Critical thinking and Chinese international students: An East-West dialogue. J. Contemp. Issues Educ. 2011, 5, 53-73. [CrossRef]

64. Chan, M.; Ho, I.; Ku, K. Epistemic beliefs and critical thinking of Chinese students. Learn. Individ. Differ. 2011, 21, 67-77. [CrossRef]

65. Floyd, C. Critical thinking in a second language. High. Educ. Res. Dev. 2011, 30, 289-302. [CrossRef]

66. Deng, M.; Pei, M. Instructions for students with special educational needs in Chinese mainstream classrooms: Modifications and barriers. Asia Pac. Educ. 2009, 10, 317-325. [CrossRef]

67. Ping, W. A case study of an in-class silent postgraduate Chinese student in London Metropolitan University: A journey of learning. TESOL J. 2010, 2, 207-214. 
68. Mak, B. An exploration of speaking-in-class anxiety with Chinese ESL learners. System 2011, 39, $202-214$. [CrossRef]

69. Liu, M.; Jackson, J. An exploration of Chinese EFL learners' unwillingness to communicate and foreign language anxiety. Mod. Lang. J. 2008, 92, 71-86. [CrossRef]

70. Zhang, Y.; Mi, Y. Another Look at the language difficulties of international students. J. Stud. Int. Educ. 2010, 14, 371-388. [CrossRef]

71. O'Loughlin, K. Developing the assessment literacy of university proficiency test users. Lang. Test. 2013, 30, 363-380. [CrossRef]

72. Alison, O.; Lee, B. Sydney harbour water has just the right amount of salt for soup: Englishes in fictionalized biographical writing. In Proceedings of the 5th Annual Popular Culture Association of Australia and New Zealand, Hobart, Australia, 18-20 June 2014.

73. Shohamy, E. Assessing multilingual competencies. Mod. Lang. J. 2011, 95, 418-429. [CrossRef]

74. $\mathrm{Ku}, \mathrm{K}$. Assessing students' critical thinking performance: Urging for measurements using multi-response format. Think. Skills Creat. 2009, 4, 70-76. [CrossRef]

75. Ryan, J.; Viete, R. Respectful interactions: Learning with international students in the English-speaking academy. Teach. High. Educ. 2009, 14, 303-314. [CrossRef]

76. Swain, M.; Kirkpatrick, A.; Cummins, J. How to Have a Guilt-Free Life Using Cantonese in the English Class: A Handbook for the English Language Teacher in Hong Kong; Research Centre into Language Acquisition and Education in Multilingual Societies, Hong Kong Institute of Education: Hong Kong, China, 2011.

77. Singh, M.; Schresta, M. International Pedagogical Structures. In Researching International Pedagogies. Sustainable Practice for Teaching and Learning in Higher Education; Hellsten, M., Reid, A., Eds.; Springer: Sydney, Australia, 2008; pp. 65-82.

78. Singh, M.; Lu, S. Post-monolingual demystification of critical thinking: Advancing intercultural divergences in education. In Demystifying Critical Thinking in Multilingual and Intercultural Education; Dervin, F., Clark, J., Eds.; Palgrave Macmillan: Basingstoke, UK, 2017; in press.

79. Kirkpatrick, R.; Zang, Y. The negative influences of exam-oriented education on Chinese high school students. Lang. Test. Asia 2011, 1, 36-45. [CrossRef]

80. Turner, Y. Students from mainland China and critical thinking in postgraduate business and management degree. Int. J. Manag. Educ. 2006, 5, 3-11. [CrossRef]

81. Marsh, J.; Rowlinson, S. CAL in construction: Attitudes to learning. In Case Studies of Improving Teaching and Learning from the Action Learning Project; Kember, D., Bick-Har, Y., Yum, J., Liu, S., Eds.; The Hong Kong Polytechnic University: Hong Kong, China, 1997; pp. 395-403.

82. Yan, K.; Berliner, C. Chinese international students in the United States: Demographic trends, motivations, acculturation features and adjustment challenges. Asia Pac. Educ. Rev. 2011, 12, 173-184. [CrossRef]

83. Bodycott, P. Embedded culture and intercultural adaptation: Implications for managing the needs of Chinese Students. J. High. Educ. Policy Manag. 2012, 34, 355-364. [CrossRef]

84. Watkins, D. Learning Theories and Approaches to Research: A Cross-Cultural Perspective. In The Chinese Learner: Cultural, Psychological, and Contextual Influences; Watkins, D., Biggs, J., Eds.; Comparative Education Research Centre: Hong Kong, China; The Australian Council for Educational Research: Melbourne, Australia, 1996.

85. Biggs, J. Western Misperceptions of the Confucian-Heritage Learning Cultures. In The Chinese Learner: Cultural, Psychological, and Contextual Influences; Watkins, D., Biggs, J., Eds.; Comparative Education Research Centre: Hong Kong, China; The Australian Council for Educational Research: Melbourne, Australia, 1996.

86. Li, L.; Wegerif, R. What does it mean to teach thinking in China? Challenging and developing notions of 'Confucian education'. Think. Skills Creat. 2014, 11, 22-32. [CrossRef]

87. Sit, H. Characteristics of Chinese students' learning styles. Int. Proc. Econ. Dev. Res. 2013, 62, 36. [CrossRef]

88. Singh, M. Worldly critical theorizing in Euro-American centered teacher education? Preparing bilingual teacher-researcher theorists for the twenty first century. In Global Teacher Education; Zhu, X., Zeichner, K., Eds.; Springer: Dordrecht, The Netherlands, 2013; pp. 141-169.

89. You, X. Rhetorical strategies, electronic media, and China English. World Engl. 2008, 27, 233-249. [CrossRef]

(c) 2017 by the authors; licensee MDPI, Basel, Switzerland. This article is an open access article distributed under the terms and conditions of the Creative Commons Attribution (CC BY) license (http:/ / creativecommons.org/licenses/by/4.0/). 